\title{
Implication of Disharmonization of Baitul Maal Wa Tamwil Establishment Laws in Indonesia
}

\author{
Ani Yunita ${ }^{1 *}$ \\ ${ }^{I}$ Faculty of Law, Universitas Muhammadiyah Yogyakarta, Indonesia \\ *E-mail:aniyunita@umy.ac.id
}

\begin{abstract}
Baitul Maal Wa Tamwil (BMT) is a type of Islamic microfinance institution that can operate with the legal entity of Cooperative and Incorporated Company. BMT, with a legal entity as a cooperative in Indonesia, poses some problems related to the legal arrangements for its establishment and inciting disharmony with others. The disharmony of the establishment of the BMT has implications for the customer's legal protection. Based on those problems, this article aims to examine the implications of disharmony in the legal arrangements of the establishment of BMTs for the legal protection of BMT customers in Indonesia. This research is a normative and empirical study with qualitative analysis methods. The results prove that the disharmony in legal arrangements of the establishment of BMTs for the legal protection of BMT customers in Indonesia resulted in the overlapping authority of BMT licensing and supervision institutions as well as weak legal protection for BMT customers in Indonesia.
\end{abstract}

Keywords: Implication, Disharmonization, Arrangement, BMT

\section{INTRODUCTION}

Baitul Maal Wa Tamwil (hereinafter written as BMT) is a microfinance institution that is operated by using the principle of profit-sharing to grow and develop micro and small businesses, increase the dignity and defend the interests of the poor based on the principles of Islamic law [1] Thus, BMT is obliged to carry out its business activities in accordance with the sharia fatwa issued by the National Sharia Council of the Indonesian Ulama Council.

BMT is a sharia financial institution that has an essential role in the midst of society. BMT not only acts as a financial service provider but also acts as amil zakat, infaq, alms, and distributes them according to regulations [2]. The presence of BMT has a positive impact on the people's economy, which seeks to reduce poverty and unemployment in Indonesia.[3]

The institutional status of BMT after the enactment of Law Number 1 of 2013 concerning Microfinance Institutions is a legal entity. The legal entity means that BMT can take the form of a Cooperative and a Limited Liability Company. BMT is a cooperative legal entity that must comply with Law Number 25 of 1992 concerning Cooperatives, while BMT that is legally incorporated as a Limited Liability Company must still refer to Law Number 40 of 2007 concerning Limited Liability Companies. BMT, as a cooperative legal entity, must carry out business activities differently compared to sharia cooperatives, where they must comply with sharia principles.

Ideally, as a form of a financial institution, BMT, licensing, guidance, and supervision are carried out by the Financial Services Authority. This is based on Law Number 21 of 2011 concerning the Financial Services Authority (hereinafter referred to as the OJK Law). In this law, it is emphasized that the Financial Services Authority has the authority to regulate, supervise, including licensing issues for all financial services sectors.

The Financial Services Authority (OJK) has the function of implementing an integrated regulatory and supervisory system for all activities in the financial services sector. Therefore, the Financial Services Authority has the authority to make regulations and supervise financial institutions. OJK, as an independent financial institution, is expected to be able to regulate and supervise as well as maximum customer protection properly [4].

On the other hand, regarding BMT licensing as above, there are also several provisions governing cooperative licensing, including Regulation of the Minister of Cooperatives, Small and Medium Enterprises of the Republic of Indonesia Number 05 of 2019 concerning Amendments to the Regulation of the Minister of Cooperatives, Small and Medium Enterprises Number 11 of 2018 concerning Cooperative Savings and Loan Business Licenses. In Regulation Number 05 of 2019, it is stated that BMT licenses are 
submitted to the Minister of Small and Medium Enterprises Cooperatives. In addition, there is also an announcement with the Ministry of Law and Human Rights, the Ministry of Cooperatives and MSMEs, the Coordinating Ministry for Economic Affairs, and the Investment Coordinating Board.

The presence of various laws and regulations related to licensing shows that there are legal problems, in the form of inconsistencies between one BMT legal arrangement and another and the occurrence of overlaps between one institution and another. The overlap between the institutions of the Ministry of Cooperatives and UMKM, the Ministry of Law and Human Rights, and the Financial Services Authority, which both have the authority to regulate BMT with cooperative legal entities. The inconsistencies in the legal arrangements for BMTs have created legal uncertainty.

According to Gustav Radbruch, a legal policy must have legal certainty. Legal certainty is one of the three terms that have value in law for the sake of upholding the rule of law. The unclear BMT regulatory policy will undoubtedly cause problems in the community. Some of these problems include the increasing number of BMTs that choose not to be a legal entity because they are deemed inappropriate by existing regulations, customers lack legal protection in the security of their investments, and overlapping regulations that make BMT problems even more complicated, and There are still several more BMT problems that occur in the community that has not been accommodated by existing regulations. ${ }^{5}$

Various problems of the regulatory aspect related to the licensing of BMTs with cooperative legal entities can be found in practice. For example, a case of a BMT customer disadvantaged by the BMT. Case in point, BMT Global Insani until 2018 did not obtain a business license either as a cooperative or a limited liability company.

Research that has been conducted by Nourma Dewi regarding the regulation of the existence of Baitul Maal Wat Tamwil (BMT) in the economic system in Indonesia. This study examines the problems regarding BMT in the Indonesian economic system in terms of regulatory aspects. The results of this study concluded that BMT management still uses a variety of regulations. This is because the special characteristics and types of legal entities in BMT can be in the form of cooperatives or limited liability companies. In contrast to previous studies, the author focuses more on discussing the implications of disharmony in the regulation of the establishment of BMTs in Indonesia, which raises several problems that have an impact on the protection of BMT customers.

Based on the above problems, the authors are interested in studying the "Implications of Disharmonization of Legal Arrangements for the Establishment of Baitul Maal Wa Tamwil in Indonesia." The focus of the problem in this study is what are the implications of disharmony in the legal arrangements for establishing BMT on legal protection for BMT customers in Indonesia. Therefore, the goal of this study is to examine the implications of disharmony in the legal arrangements for establishing BMT on legal protection for BMT customers in Indonesia.

\section{LITERATURE REVIEW}

\subsection{The Definitions of Baitul Maal Wa Tamwil (BMT)}

The word Baitul Maal Wa Tamwil (BMT) comes from the two terms, baitul mal and baitul tamwil. ${ }^{6}$ A more specific definition can be derived as follows: 1 . Baitul maal means the house of wealth, which refers to the social mission of BMT as an institution that distributes the donation of zakat, infaq, and shadaqah to the persons who are eligible to receive (Mustahiq). 2. Baitul tamwil means the house of wealth development, which is the business mission of BMT. It is meant to conduct business development efforts and investments in the productive economy in order to improve the quality of micro and small entrepreneurs, especially by encouraging saving activities and supporting the financing of economic activities.

Baitul Maal Wa Tamwil (BMT) is an integrated independent business center that operates the bayt al-mal wa at-tamwil operations. BMT carries out activities by developing productive and investment businesses to improve the quality of economic activities ${ }^{7}$. In addition, BMT can also receive zakat, infaq, alms, and distribute according to regulations. BMT is an informal Islamic financial institution because a non-governmental organization founded this institution ${ }^{8}$.

Another definition was put forward by Amin Azis, who stated that BMT is an "Integrated Independent Business Center which was developed from the concept of baitul mal wat tamwil. In terms of baitul mal, BMT received BAZIS deposits from zakat, infaq and shadaqah funds. These funds can be used to improve the welfare of the poor. In the baitul tamwil aspect, BMT develops productive businesses and is used to increase the income of small entrepreneurs and BMT members ${ }^{9}$.

Based on the above definition, BMT has 2 (two) functions ${ }^{10}$.

1. Bait at maal (bait means house, maal means property) accepts zakat, donations alms, and optimizes its distribution in accordance with the regulations and mandates.

2. Bait at tamwil (bait means house, at tamwil means development of assets) carries out activities for developing productive businesses and investing in improving the economic quality of macro and small entrepreneurs, especially by encouraging savings activities and supporting 
the financing of their economic activities.

\subsection{Legal Arrangements for Baitul Maal wa Tamwil}

The legal arrangements for BMT are regulated in the Al Quran, Hadith, Fatwa of the National Sharia Council-Indonesian Ulema Council, and several statutory regulations as follows:

\subsubsection{Al-Quran}

a. Surah At Taubah verses 60 and 103 .

1) Surah At Taubah verse 60

"Zakah expenditures are only for the poor and for the needy and for those employed to collect [zakah] and for bringing hearts together [for Islam] and for freeing captives [or slaves] and for those in debt and for the cause of Allah and for the [stranded] traveler an obligation [imposed] by Allah. And Allah is Knowing and Wise."

2) Surah At Taubah verse 103.

"Take, [O, Muhammad], from their wealth a charity by which you purify them and cause them increase, and invoke [Allah's blessings] upon them. Indeed, your invocations are reassurance for them. And Allah is Hearing and Knowing."

b. Surah Al Baqarah verse 275

"Those who consume interest cannot stand [on the Day of Resurrection] except as one stands who is being beaten by Satan into insanity. That is because they say, "Trade is [just] like interest." But Allah has permitted trade and has forbidden interest. So whoever has received an admonition from his Lord and desists may have what is past, and his affair rests with Allah. But whoever returns to [dealing in interest or usury] - those are the companions of the Fire; they will abide eternally therein."

c. Surah Al Baqarah verses 278-279

"O you who have believed, fear Allah and give up what remains [due to you] of interest, if you should be believers. And if you do not, then be informed of a war [against you] from Allah and His Messenger. But if you repent, you may have your principal - [thus] you do no wrong, nor are you wronged."
2.2.2. Hadith Muslim number. 2971, in Al Masaqqah

"It was narrated by $\mathrm{Abu}$ Said $\mathrm{Al}$ Khudri that the Messenger of Allah said," Gold should be paid in gold, silver with silver, wheat with wheat, flour with flour, dates with dates, salt with salt, the payment must be from hand to hand (cash). Whoever gives additional or asks for additional, in fact he has dealt with usury. The recipient and the giver are both guilty."

\subsubsection{The provisions of the Fatwa of the National Sharia Council-Indonesian Ulama Council which regulate Baitul Maal Wat Tamwil are as follows:}

a) MUI DSN Fatwa No. 07/ DSN-MUI /IV / 2000 concerning Mudharabah Financing.

b) MUI DSN Fatwa No. 08/ DSN-MUI/ IV / 2000 concerning Musharaka Financing.

c) MUI DSN Fatwa No. 04/ DSN-MUI / IV / 2000 regarding Murabaha.

d) MUI DSN Fatwa No. 05/ DSN-MUI/ IV / 2000 regarding Buying and Selling Salam.

e) MUI DSN Fatwa No. 06/ DSN-MUI/ IV /2000 regarding Buying and Selling Istishna.

f) MUI DSN Fatwa No. 09/ DSN-MUI/ IV / 2000 regarding Ijarah Financing.

g) MUI DSN Fatwa No. 27/ DSN-MUI/ III / 2002 concerning Al-Ijarah Al-Mutahiyah bi AlTamlik.

h) MUI DSN Fatwa No. 19/ DSN-MUI/ IX / 2000 on al Qardh.

In addition to the philosophical foundations contained in the Al-Qur'an and hadiths, BMT is also regulated in several regulations that govern it according to the form of the BMT legal entity itself. Regulations regarding the institutional status of BMT before the enactment of the Law on Microfinance Institutions are as follows:

1. BMT is a cooperative in the form of a Sharia Financial Services Cooperative based on Law Number 25 of 1992 concerning Cooperatives.

2. BMT, as a foundation-owned enterprise, must refer to Law Number 25 of 1992 concerning Cooperatives as well as to Law Number 28 of 2004 concerning Amendments to Law Number 16 of 2001 concerning Foundations.

3. BMT, which is a Limited Liability Company, must be based on Law Number 40 of 2007 concerning Limited Liability Companies.

4. BMT which is still in the form of a NonGovernmental Organization (KSM) based on Law 
Number 17 of 2013 concerning Community Organization.

The regulations governing BMT after the enactment of the Law on Microfinance Institutions include the following ${ }^{11}$ :

1. Law Number 1 of 2013 concerning Microfinance Institutions;

2. Government Regulation number 89 of 2014 concerning Loan Interest Rates or Returns on Financing and the Area of Microfinance Institutions' Business Areas;

3. Regulation of the Minister of Cooperatives and Small and Medium Enterprises of the Republic of Indonesia Number 05 of 2019 concerning Amendments to the Regulation of the Minister of Cooperatives, Small and Medium Enterprises Number 11 of 2018 concerning Cooperative Savings and Loan Business Licenses.

4. Financial Services Authority Circular Letter (SEOJK) number 29/SEOJK.05/2015 concerning Micro Financial Institutions Financial Reports;

5. Financial Services Authority Regulations (POJK):

a. POJK Number 12/POJK.05/2014 concerning Business Licensing and Institutional Microfinance Institutions.

b. POJK Number 13/POJK.05/ 2014 concerning the Implementation of Microfinance Institutions Businesses.

c. POJK Number 14/POJK.05/2014 concerning Development and Supervision of Micro Financial Institutions.

d. POJK Number 61/POJK.05/ 2015 concerning Amendments to the Financial Services Authority Regulation Number 12/POJK.05/2014 concerning Business Licensing and Institutional Microfinance Institutions.

e. POJK Number 62/POJK.05/2015 concerning Amendments to the Financial Services Authority Regulation Number 13/POJK.05/2014 concerning the Implementation of Micro Financial Institutions Business.

f. Joint Announcement of the Ministry of Law and Human Rights, the Ministry of Cooperatives and Micro Small and Medium Enterprises (MSMEs), the Coordinating Ministry for Economic Affairs and the Investment Coordinating Board.

\section{RESEARCH METHODS}

\subsection{Type of Research}

One of the essential factors in research that supports the preparation of writing scientific papers is the solution to the problem under study. The topic of the problems studied in this research is about legal issues (the law is a rule or norm that exists in society), so the type in the legal research proposal used by the author is normative research. Normative research is research conducted by studying legal materials such as laws and regulations $^{12}$ regarding BMT regulation, books on BMT and its problems, papers, scientific publications related to the issues under study.

\subsection{Types and Sources of Data}

The type of data used in this study is secondary data. Secondary data is sourced from documented data in the form of legal materials. Secondary data consists of primary legal materials and secondary legal materials. The primary legal materials are Law Number 1 Year 2013, Financial Services Authority Regulation Number 12/POJK.05/2014 concerning Business Licensing and Institutional Microfinance Institutions, POJK Number 13/POJK.05/2014 concerning Micro Financial Institution Business Operations and Regulations Minister of Cooperatives, Small and Medium Enterprises of the Republic of Indonesia Number 05 of 2019 concerning Amendments to the Regulation of the Minister of Cooperatives, Small and Medium Enterprises Number 11 of 2018 concerning Cooperative Savings and Loan Business Licenses. Secondary legal materials consist of books on BMT, microfinance institutions, legal theory, legal research methodologies, journals, and proceedings.

\subsection{Data Collection Techniques}

Data collection techniques were to obtain secondary data sources, namely through data collection by observation and literature searches. The technique of collecting data through observation means that the researcher is not involved in the activities carried out by the actors being observed. Researchers only focus on certain things that are considered essential and relevant to the problem to be studied.

The data collection technique in this research is through literature search by reviewing documents, laws, regulations, and books related to sharia economic law, Islamic financial institutions, and Baitul Maal Wa Tamwil. Document or library study is a data collection tool that is carried out through written data. ${ }^{13}$ Thus, researchers used literature searches to complement the results of the observations in this study.

\subsection{Data Analysis}

The data obtained from library research is processed based on qualitative analysis. The analysis of legal materials used by the author in this study is an evaluation using a qualitative approach by describing the data in the form of systematically arranged sentences. Therefore, this research describing about the implications of disharmony in the legal arrangements for establishing BMT on legal protection for BMT customers in Indonesia. 


\section{DISCUSSION}

Sharia Microfinance institutions have a significant role to play in supporting government programs to alleviate poverty ${ }^{14}$. Basically, microfinance institutions were formed based on Article 27 paragraph (2) and Article 33 of the 1945 Constitution. Article 27 paragraph (2) which states that every citizen has the right to work and a decent living for humanity. This article explains that every individual, as a member of the citizen, has the right to get a decent job and life in social life. Article 33 of the 1945 Constitution states that the economy is structured as a joint effort based on the principle of kinship as BMT is established based on the principle of kinship.

One of the micro-financial institutions is BMT, which is an Micro Financial Institution with sharia principles ${ }^{15}$. BMT, as a legal entity that has business activities, must provide financial services based on sharia principles. Therefore, An Islamic financial system should also cater to the social needs of society ${ }^{16}$. In this case, BMTs must be given supervision by the Sharia Supervisory Board, which is tasked with providing advice to the board of directors or management and supervising the activities of sharia microfinance institutions in accordance with sharia principles.

BMT is one of the Islamic financial institutions whose role is to protect the middle and lower class society from the interest system applied by conventional institutions as well as from moneylenders who pay high interest to their customers. BMT is different from other financial institutions that provide consumptive financing so that the people's economy tends to be consumptive. BMT tends to provide financing in the form of working capital to people who have microbusinesses. BMT encourages people to be more creative and productive so that they can improve the economy of people who have middle to lower economies.

There are several legal arrangements regarding microfinance institutions, but there is no specific regulation that regulates BMT so that there are inconsistencies between one and another. This has resulted in weak legal protection for BMT customers who experience losses due to actions by BMT institutions. ${ }^{17}$

Regulations regarding the institutional status of BMT before the enactment of the MFI Law are in the following regulations: ${ }^{18}$

1. BMT is a cooperative in the form of a Sharia Financial Services Cooperative based on Law Number 25 of 1992 concerning Cooperatives. Furthermore, in business activities subject to the following conditions:

a. Decree of the State Minister for Cooperatives, Small and Medium Enterprises Number 91/Kep/M.KUKM/IX/2004 concerning Guidelines for the Implementation of Islamic
Financial Services Cooperative Business Activities,

b. Regulation of the State Minister for Cooperatives, Small and Medium Enterprises 35.2/Per/M.KUKM/X/2007 concerning Guidelines for Standard Operational Management of Islamic Financial Services Cooperatives, and

c. Regulation of the State Minister for Cooperatives, Small and Medium Enterprises 39/Per/M.KUKM/XII/2007 concerning Guidelines for Supervision of Sharia Financial Services Cooperatives and Cooperative Sharia Financial Services Units.

2. BMT, as a foundation-owned enterprise, must refer to Law Number 25 of 1992 concerning Cooperatives as well as to Law Number 28 of 2004 concerning Amendments to Law Number 16 of 2001 concerning Foundations.

3. BMT, which is a Limited Liability Company, must be based on Law Number 40 of 2007 concerning Limited Liability Companies.

4. BMT which is still in the form of a NonGovernmental Organization (KSM) based on Law Number 17 of 2013 concerning Community Organization.

The regulations governing BMT after the enactment of the Law on Microfinance Institutions include the following:

1. Law Number 1 of 2013 concerning Microfinance Institutions;

2. Government Regulation number 89 of 2014 concerning Loan Interest Rates or Returns on Financing and the Area of Microfinance Institutions' Business Areas;

3. Regulation of the Minister of Cooperatives and Small and Medium Enterprises of the Republic of Indonesia Number 05 of 2019 concerning Amendments to the Regulation of the Minister of Cooperatives and Small and Medium Enterprises Number 11 of 2018 concerning Cooperative Savings and Loan Business Licenses.

4. Financial Services Authority Circular Letter (SEOJK) number 29/SEOJK.05/2015 concerning Micro Financial Institutions Financial Reports;

5. Financial Services Authority Regulations (POJK):
a. POJK Number 12/POJK.05/2014 concerning Business Licensing and Institutional Microfinance Institutions.
b. POJK Number 13/POJK.05/2014 concerning the Implementation of Microfinance Institutions Businesses.
c. POJK Number 14/POJK.05/2014 concerning Development and Supervision of Micro Financial Institutions.
d. POJK Number 61/POJK.05/2015 concerning Amendments to the Financial


Services Authority Regulation Number 12/POJK.05/ 2014 concerning Business Licensing and Institutional Microfinance Institutions.

e. POJK Number 62/POJK.05/2015 concerning Amendments to the Financial Services Authority Regulation Number 13/POJK.05/ 2014 concerning the Implementation of Micro Financial Institutions Business.

6. Joint Announcement of the Ministry of Law and Human Rights, the Ministry of Cooperatives and MSMEs, the Coordinating Ministry for Economic Affairs and the Investment Coordinating Board.

After the enactment of Law Number 1 of 2013, BMT is said to be one of the micro financial institutions if it has the status of a cooperative legal entity, as stated in Article 4 of Law Number 1 of 2013 concerning Micro Financial Institutions that the establishment of an Micro Financial Institution must at least have following requirements:

a. Legal entity

b. Capital; and obtain a business license whose procedures are regulated in this law.

The form of legal entity in question is a cooperative or limited liability company. If the financial institution is a cooperative, it will refer to Law Number 25 of 1992 concerning Cooperatives. If the financial institution is a Limited Liability Company, then it is based on Law Number 40 of 2007 concerning Limited Liability Companies. Thus, the various BMT regulations result in overlapping regulations issued by each agency.

According to Article 5, POJK Number 61/POJK.05/ 2015 concerning Amendments to the Financial Services Authority Regulation Number 12/POJK.05/2014 concerning Business Licensing and Institutional Microfinance Institutions, it is clear that BMTs in carrying out their business activities are required to license the Financial Services Authority. This is also reinforced in Article 9 Law Number 1 of 2013 concerning Micro Financial Institution Law, which states that licensing for microfinance institutions, including BMT, is required to apply for a permit to the Financial Services Authority (OJK).

Unlike the case with the Regulation of the Minister of Cooperatives, Small and Medium Enterprises of the Republic of Indonesia Number 05 of 2019 concerning Cooperative Savings and Loan Business Licensing which regulates that cooperatives in carrying out their business activities must obtain permission from the Ministry of Cooperatives and MSMEs while the Joint Announcement of the Ministry of Law and Human Rights, Ministry Cooperatives and MSMEs, the Coordinating Ministry for Economic Affairs and the Investment Coordinating Board explained that with the issuance of Government Regulation Number 24 of 2018 concerning Integrated Business Licensing Services electronically, there was a transfer of authority to ratify the deed of establishment, amendment, and dissolution of cooperatives which was previously transferred by the Ministry of Cooperatives and Micro Small and Medium Enterprises (MSMEs) to Ministry of Law and Human Rights. Therefore, several licensing provisions governing the establishment of such BMTs show inconsistencies between one licensing arrangement and others.

With the existence of several legal arrangements regarding BMTs with cooperative legal entities, in this case, at the same time, it raises problems with legal problems with licensing arrangements as well as a problem with institutional authorities that carry out licensing, guidance, and supervision of BMTs with cooperative legal entities. This will imply an overlapping of authority, as previously explained.

BMT, as a sharia cooperative, must be carried out in the spirit of democracy and sharia. The spirit of democracy as the embodiment of the spirit of democracy in the country of Indonesia and the spirit of sharia as a characteristic of Islam which upholds the principles of sharia such as justice, unity, and balance in all activities carried out. Thus, if the institutional status of BMTs that are legal cooperatives is regulated clearly and comprehensively, it will not imply inconsistencies or overlaps between one regulation and another. This will also affect the protection of BMT customers.

Legal protection, according to Satjipto Raharjo, states that it provides protection to human rights that are harmed by others and that protection is given to the community so that they can enjoy all the rights provided by law. ${ }^{19}$ This protection is given to the community so that they can enjoy their rights as citizens. The community (in this case, the customer) has rights that must be fulfilled by the BMT, even though the institution has been frozen. This is a form of BMT responsibility to its customers according to applicable regulations.

According to Philipus M. Hadjon, legal protection is the protection of dignity and recognition of human rights possessed by legal subjects in the rule of law. The legal protection must be based on the applicable legal provisions in the country in order to prevent arbitrariness. Thus, the law functions as a protection for human interests. ${ }^{20}$

This legal protection is provided to customers to provide a sense of security to BMT customers. Not a few of them who come from low-income economies join in developing their micro-businesses. BMT customers must receive legal protection from the behavior of irresponsible people. Therefore, it is necessary to have good communication as well as legal substance and legal awareness for BMT agency actors so that BMT can run well and in balance without having to be harmed by either party. 
The case that occurs in the community is a BMT customer who is disadvantaged by the BMT. Case in point, BMT Global Insani until 2018 did not obtain a business license either as a cooperative or a limited liability company. Seeing these problems, financial losses experienced by customers become problems for customers, which have an impact on the customer's socio-economic conditions. It also causes social impact, such as the emergence of negative views from society towards customers. Economically, customers will lose a nominal amount of money, which is certainly not small. They only get money from long-term savings or maybe the results of borrowing from banks and third parties.

Clear legal protection for BMT customers should provide a basis for resolving disputes that occur at BMT. BMT currently refers to Law Number 1 of 2013 concerning MFIs and is subject to several regulations that vary according to its institution, such as subject to Law Number 25 of 1992 concerning cooperatives and Law Number 40 of 2007 concerning PT and other cooperative regulations. Thus, it is necessary to reconstruct a special/one-stop legal arrangement related to BMT licensing and sharia customer deposit insurance rules to ensure customer legal protection.

\section{CONCLUSIONS}

Based on this study, it is concluded that the implications of disharmony in the legal arrangements for the establishment of BMTs on the legal protection of BMT customers in Indonesia have resulted in the overlapping authority of BMT licensing and supervision institutions, namely the Financial Services Authority, the Ministry of Cooperatives and Micro Small and Medium Enterprises (MSMEs), the Ministry of Law and Human Rights. In addition, the disharmony of BMT regulations has implications for the weak legal protection of BMT customers in Indonesia.

\section{RECOMMENDATION}

The recommendation that can be given by the author is that special arrangements regarding BMT legal cooperatives should be formed immediately so that there is no inconsistency in the legal arrangements of BMTs. Ideally, the regulation, licensing, guidance, and supervision of BMTs is under the authority of the Financial Services Authority so that there is no overlapping of institutions that regulate the establishment of BMTs.

\section{ACKNOWLEDGMENT}

The author would like to thank the Faculty of Law, Universitas Muhammadiyah Yogyakarta, for facilitating and supporting the process of writing this article well and smoothly. The author also thanks to the International Conference on Sustainable Innovation (ICOSI) Team of Universitas Muhammadiyah
Yogyakarta 2020, which has provided the opportunity and support to the author to write this article well.

\section{REFERENCES}

[1] Ani Yunita et all. Pengantar Hukum Perbankan dan Lembaga Keuangan Islam. Yogyakarta. Pustaka Pelajar.2019 pp.199.

[2] Andri Soemitra. Bank\& Lembaga Keuangan Syariah. Jakarta. Kencana Prenada Media Group.2009.pp.448

[3] Zulkifli Rusby et all.Analisa Permasalahan Baitul Maal Wa Tamwil Melalui Pendekatan Analytical Network Process. Jurnal Al-hikmah Vol. 13, No. 1, April 2016, pp. 18.

[4] Ani Yunita et all. Tanggung Jawab Otoritas Jasa Keuangan Solo Terhadap Pengelolaan Dana Pensiun Syariah Di Lembaga Dana Pensiun Universitas Muhammadiyah Surakarta. Jurnal Masalah-Masalah Hukum, Jilid 47. No.4. Oktober 2018, pp. 463.

[5] Fadilah Mursid. Kebijakan Regulasi Baitul Maal Wat Tamwil (Bmt) Di Indonesia. Nurani, Vol. 18, No. 2, Desember 2018. pp.11.

[6] Wahibur Rokhman. Baitul Mal Wat Tamwil (Bmt) And Poverty Empowerment. Qudus International Journal of Islamic Studies. Volume 1. Number 2. July-December 2013. pp.183.

[7] Muljadi. Operationalization of Shariah Marketing Mix in Baitul Maal Wat Tamwil (BMT) at the Province of Banten, Indonesia. Review Of Integrative Business \& Economics Research. Vol 4(1).2014.pp.41.

[8] Neni Sri Imaniyati. Aspek-Aspek Hukum Baitul Maal Wat Tamwil (BMT) dalam Perspektif Hukum Ekonomi. Prosiding SNaPP2011: Sosial, Ekonomi, dan Humaniora. pp.130.

[9] Ahmad Hasan Ridwan. Manajemen Baitul Mal Wa Tamwil. Bandung. CV Pustaka Setia. 2013.pp.23

[10] Anonim, Lembaga Keuangan Syariah dan Konvensional Untuk Permodalan UMKM, https://goukm.id/lembagakeuangan-mikro/ Lembaga Keuangan Syariah dan Konvensional Untuk Permodalan UMKM diakses tanggal 28 November 2019 pukul 17.00wib.

[11] Peter Mahmud Marzuki. Penelitian Hukum. Jakarta: Kencana.2005.pp.93.

[12] Soerjono Soekanto. Pengantar Penelitian Hukum. Jakarta: Penerbit UI. 2006. pp.21

[13] Kuat Ismanto et all, "Perceptions and Reconstruction of Customers' Trust of Baitul Maal wa Tamwil (BMT) in Pekalongan".International Journal of Islamic Business and Economics. 1 (1) June 2017.pp.56.

[14] Nourma Dewi. 2017. Regulasi Keberadaan Baitul Maal Wa Tamwil (BMT) Dalam Sistem Perekonomian Di Indonesia. Jurnal Serambi Hukum. Vol 11. No.01 Februari-Juli.pp.96.

[15] Habib Ahmed. 2014.Islamic Banking and Shariah Compliance: A Product Development Perspective. Journal of Islamic Finance, 3(2), pp.16.

[16] Fitriani Prastiawati \& Emile Satia Darma. Peran Pembiayaan Baitul Maal Wat Tamwil Terhadap Perkembangan Usaha dan Peningkatan Kesejahteraan Anggotanya dari Sektor Mikro Pedagang Pasar Tradisional. Jurnal Akuntansi dan Investasi, Vol. 17 No. 2. 2016.pp.197.

[17] Novita Dewi Masyithoh. Analisis Normatif UndangUndang Nomor 1 Tahun 2013 tentang Lembaga Keuangan Mikro (LKM) atas Status Badan Hukum dan Pengawasan BMT. Economica. Vol V, Edisi 2, Oktober 2014.pp.29. 
[18] Sajipto Rahardjo. Sisi-sisi lain dari Hukum di Indonesia. Jakarta: Kompas. pp.121.
[19] Philipus M. Hadjon. Perlindungan Hukum Bagi Rakyat di Indonesia. Surabaya: Peradaban. 2007.pp.2-5.
${ }^{1}$ Ani Yunita et all. Pengantar Hukum Perbankan dan Lembaga Keuangan Islam. Yogyakarta. Pustaka Pelajar.2019 pp.199.

${ }^{2}$ Andri Soemitra. Bank\& Lembaga Keuangan Syariah. Jakarta. Kencana Prenada Media Group.2009.pp.448

${ }^{3}$ Zulkifli Rusby et all.Analisa Permasalahan Baitul Maal Wa Tamwil Melalui Pendekatan Analytical Network Process. Jurnal Al-hikmah Vol. 13, No. 1, April 2016, pp.18.

${ }^{4}$ Ani Yunita et all. Tanggung Jawab Otoritas Jasa Keuangan Solo Terhadap Pengelolaan Dana Pensiun Syariah Di Lembaga Dana Pensiun Universitas Muhammadiyah Surakarta. Jurnal Masalah-Masalah Hukum, Jilid 47. No.4. Oktober 2018, pp. 463.

${ }^{5}$ Fadilah Mursid. Kebijakan Regulasi Baitul Maal Wat Tamwil (Bmt) Di Indonesia. Nurani, Vol. 18, No. 2, Desember 2018. pp.11.

${ }^{6}$ Wahibur Rokhman. Baitul Mal Wat Tamwil (Bmt) And Poverty Empowerment. Qudus International Journal of Islamic Studies. Volume 1. Number 2. JulyDecember 2013. pp.183.

7 Muljadi. Operationalization of Shariah Marketing Mix in Baitul Maal Wat Tamwil (BMT) at the Province of Banten, Indonesia. Review of Integrative Business \& Economics Research. Vol 4(1).2014.pp.41.

9 Neni Sri Imaniyati. Aspek-Aspek Hukum Baitul Maal Wat Tamwil (BMT) dalam Perspektif Hukum Ekonomi. Prosiding SNaPP2011: Sosial, Ekonomi, dan Humaniora. pp.130.

${ }^{10}$ Ahmad Hasan Ridwan. Manajemen Baitul Mal Wa Tamwil. Bandung. CV Pustaka Setia. 2013.pp.23

${ }^{11}$ Anonim, Lembaga Keuangan Syariah dan Konvensional Untuk Permodalan UMKM, https://goukm.id/lembaga-keuangan-mikro/ Lembaga
Keuangan Syariah dan Konvensional Untuk Permodalan UMKM diakses tanggal 28 November 2019 pukul 17.00wib.

12 Peter Mahmud Marzuki. Penelitian Hukum. Jakarta: Kencana.2005.pp.93.

${ }^{13}$ Soerjono Soekanto. Pengantar Penelitian Hukum. Jakarta: Penerbit UI. 2006. pp.21.

${ }^{14}$ Kuat Ismanto et all, "Perceptions and Reconstruction of Customers' Trust of Baitul Maal wa Tamwil (BMT) in Pekalongan".International Journal of Islamic Business and Economics. 1 (1) June 2017.pp.56.

${ }^{15}$ Nourma Dewi. 2017. Regulasi Keberadaan Baitul Maal Wa Tamwil (BMT) Dalam Sistem Perekonomian Di Indonesia. Jurnal Serambi Hukum. Vol 11. No.01 Februari-Juli.pp.96.

${ }^{16}$ Habib Ahmed. 2014.Islamic Banking and Shariah Compliance: A Product Development

Perspective. Journal of Islamic Finance, 3(2), pp.16.

${ }^{17}$ Fitriani Prastiawati \& Emile Satia Darma. Peran Pembiayaan Baitul Maal Wat Tamwil Terhadap Perkembangan Usaha dan Peningkatan Kesejahteraan Anggotanya dari Sektor Mikro Pedagang Pasar Tradisional. Jurnal Akuntansi dan Investasi, Vol. 17 No. 2. 2016.pp.197.

${ }^{18}$ Novita Dewi Masyithoh. Analisis Normatif Undang-Undang Nomor 1 Tahun 2013 tentang Lembaga Keuangan Mikro (LKM) atas Status Badan Hukum dan Pengawasan BMT. Economica. Vol V, Edisi 2, Oktober 2014.pp.29.

${ }^{19}$ Sajipto Rahardjo. Sisi-sisi lain dari Hukum di Indonesia. Jakarta: Kompas. pp.121.

${ }^{20}$ Philipus M. Hadjon. Perlindungan Hukum Bagi Rakyat di Indonesia. Surabaya: Peradaban. 2007.pp.2-5. 